\title{
Fear of storms and hurricanes in Antillean and Belgian Children
}

Citation for published version (APA):

Muris, P. E. H. M., Meesters, C. M. G., Merckelbach, H. L. G. J., Verschuren, P. M., Geebelen, E., \& Aleva, E. (2002). Fear of storms and hurricanes in Antillean and Belgian Children. Behaviour Research and Therapy, 40(4), 459-469. https://doi.org/10.1016/S0005-7967(01)00058-4

Document status and date:

Published: 01/01/2002

DOI:

10.1016/S0005-7967(01)00058-4

Document Version:

Publisher's PDF, also known as Version of record

\section{Please check the document version of this publication:}

- A submitted manuscript is the version of the article upon submission and before peer-review. There can be important differences between the submitted version and the official published version of record.

People interested in the research are advised to contact the author for the final version of the publication, or visit the DOI to the publisher's website.

- The final author version and the galley proof are versions of the publication after peer review.

- The final published version features the final layout of the paper including the volume, issue and page numbers.

Link to publication

\footnotetext{
General rights rights.

- You may freely distribute the URL identifying the publication in the public portal. please follow below link for the End User Agreement:

www.umlib.nl/taverne-license

Take down policy

If you believe that this document breaches copyright please contact us at:

repository@maastrichtuniversity.nl

providing details and we will investigate your claim.
}

Copyright and moral rights for the publications made accessible in the public portal are retained by the authors and/or other copyright owners and it is a condition of accessing publications that users recognise and abide by the legal requirements associated with these

- Users may download and print one copy of any publication from the public portal for the purpose of private study or research.

- You may not further distribute the material or use it for any profit-making activity or commercial gain

If the publication is distributed under the terms of Article $25 \mathrm{fa}$ of the Dutch Copyright Act, indicated by the "Taverne" license above, 


\title{
BEHAVIOUR
}

RESEARCH AND

THERAPY

\section{Fear of storms and hurricanes in Antillean and Belgian children}

\author{
Peter Muris ${ }^{\mathrm{a},{ }^{*}}$, Cor Meesters a, Harald Merckelbach ${ }^{\mathrm{b}}$, Mariëlle Verschuren ${ }^{\mathrm{a}}$, \\ Elke Geebelen ${ }^{\mathrm{a}}$, Elisabeth Aleva ${ }^{\mathrm{c}}$ \\ ${ }^{a}$ Department of Medical, Clinical, and Experimental Psychology, Maastricht University, Maastricht, The \\ Netherlands \\ ${ }^{\mathrm{b}}$ Department of Experimental Psychology, Maastricht University, Maastricht, The Netherlands \\ ${ }^{\mathrm{c}}$ Department of Developmental Psychology, Utrecht University, Utrecht, The Netherlands
}

Received 13 March 2001

\begin{abstract}
The present study assessed fear of hurricanes in children who had been confronted with this natural event (i.e., Antillean children, $n=161$ ). Their fear levels were compared to those of children who are unfamiliar with such an event (i.e., Belgian children, $n=185$ ). Antillean children reported significantly higher levels of fear of storms than Belgian children did, thus providing support for the notion that exposure to dangerous events promotes children's fears of those events. Surprisingly, however, Antillean children had lower scores on the 'Hurricanes' item than Belgian children. Plausibly, differences in how children interpreted this item may have accounted for this unexpected finding. That is, ratings of Antillean children were probably based on actual experiences with hurricanes, whereas scores of Belgian children presumably reflected appraisal of threat in case they would be confronted with such an event. Implications of this finding for the assessment of childhood fears are briefly discussed. (C) 2002 Elsevier Science Ltd. All rights reserved.
\end{abstract}

Keywords: Fear of storms and hurricanes; Children; Fear Survey Schedule for Children

\section{Introduction}

At least in older children, fears are mostly related to situations or cues that are potentially dangerous in the sense that they may cause physical harm (Gullone, 2000; King, Hamilton, \&

\footnotetext{
* Corresponding author.

E-mail address: p.muris@dep.unimaas.nl (P. Muris).
} 
Ollendick, 1988; Muris \& Merckelbach, 2001; Ollendick, King, \& Muris, submitted). For example, studies employing the Fear Survey Schedule for Children (FSSC; Ollendick, 1983) have consistently reported the following rank order for common childhood fears: (1) Not being able to breathe, (2) Being hit by a car or truck, (3) Bombing attacks, (4) Getting burned by fire, (5) Falling from a high place, (6) Burglar breaking into the house, (7) Earthquake, (8) Death, (9) Getting a serious disease, and (10) Snakes (e.g., Ollendick, King, \& Frary, 1989; Ollendick, Yule, \& Ollier, 1991; Ollendick \& King, 1994). There is also evidence showing that these top intense fears are quite similar across children from different nationalities (e.g., Ollendick, Yang, King, Dong, \& Akande, 1996).

There are good reasons to believe that the majority of common childhood fears develops as a result of indirect learning processes (see for a review, King, Gullone, \& Ollendick, 1998). A good example is provided by the study of Ollendick and King (1991) who evaluated to what extent Rachman's (1977) theory of fear acquisition can be applied to the 10 most prevalent childhood fears. Children who reported "a lot of fear" to FSSC items such as "Not being able to breathe" and "Being hit by a car or truck" were asked to indicate whether (1) they remembered having a bad or frightening experience with the feared stimulus or situation (i.e., direct conditioning), (2) their parents or friends ever showed fear or avoidance of the feared stimulus or situation (i.e., modeling), and/or (3) they had heard frightening things about the feared stimulus or situation from their parents, teachers, television, and so on (i.e., exposure to negative information). Results showed that the majority of children attributed the onset of their fear to information (89\%) and modeling (56\%) experiences rather than to direct conditioning events (36\%).

Although informational learning seems to play an important role in the emergence of common childhood fears related to danger and physical harm, there is also some evidence showing that actual exposure to life-threatening events such as natural and human-made disasters may promote children's fears. For example, Dollinger, O'Donnell, and Staley (1984) examined children's fears following a fatal lightning strike. During a children's football match, the pitch was struck by lightning and most of the players and spectators were knocked down. Several children were taken to the hospital and one child even died. Twenty-nine children who witnessed the incident and 29 controls completed a fear questionnaire. Fear of lightning and other stimuli and situations related to the traumatic indicident (e.g., death, dying, noise) were found to be more common among children who witnessed the incident than among control children. In a further study, Yule, Udwin, and Murdoch (1990) administered the FSSC to children who survived the sinking of a cruise ship. As expected, cruise survivors displayed significantly higher levels of fear of stimuli associated with the traumatic accident than control children.

The current study made a further attempt to examine to what extent actual exposure to a dangerous event affects children's fears. For this purpose, we assessed fears of storms and hurricanes in children who lived in St Maarten (The Netherlands Antilles) which is a small island in the Carribean. During the past 5 years, this island has been seriously ravaged by two hurricanes (i.e., Luis in 1995 and Lenny in 1999). As a control group, we recruited children from Belgium, a European country which has a relatively mild climate with occasional storms, but no hurricanes. To both groups of children, the following two instruments were administered: the HurricaneStorm Questionnaire (HSQ), which is a brief scale for assessing fear of storms and hurricanes, and the short 25-item version of the FSSC, which is an inventory assessing children's fear levels in five domains, namely fear of danger and death, fear of the unknown, fear of animals, fear of 
failure and criticism, and medical fear. It was predicted that Antillean children would display more storms and hurricanes related fears than would Belgian children. Furthermore, we expected that the two groups would not differ with regard to general fear levels.

\section{Method}

\subsection{Participants}

The study was carried out in the first months of 2000. Participants were 161 children (61 boys and 100 girls) from five primary schools of St Maarten, The Netherlands Antilles. Children had a mean age of 9.5 years ( $\mathrm{SD}=1.1$, range $8-11$ years). The majority of the Antillean children was black or had a mixed ethnical background, while only $5 \%$ of these children was Caucasian. About $30 \%$ of these children came from divorced families. The comparison group consisted of 185 Belgian children (124 boys and 130 girls) with a mean age of 9.8 years ( $\mathrm{SD}=0.9$, range 8-11 years). Most of them $(>95 \%)$ were Caucasian and about $15 \%$ came from divorced families.

We had no access to information about the socio-economic status of the children, but it seems safe to assume that Belgian children came from families with a higher economic status than that of the families of Antillean children.

\subsection{Questionnaires}

The $H S Q$ is a brief scale that was construed for the purpose of the present study. It consists of two parts. The first part comprises a single item, namely "How much do you fear a hurricane?" that is rated on a 3-point scale (1=no fear, 2=some fear, 3=a lot of fear). The second part consists of 8 items referring to potentially fearful stimuli and situations associated with severe storms (see Table 2). Again, each item is rated on a 3-point scale (1=no fear, 2=some fear, 3=a lot of fear). Scores were summed to yield a total fear of storms score (range 8-24). It is important to note that children from the two countries used their own frame of reference when completing the fear of storm items. Thus, Antillean children were asked to think of their experiences with hurricanes when answering these questions, whereas Belgian children were asked to think of their experiences with storms.

The short version of the FSSC is a 25 -item measure derived from the original FSSC by taking 5 prevalent items that are known to load convincingly on each of the 5 fear factors: fear of failure and criticism (e.g., "Making mistakes"), fear of the unknown (e.g., "Going to bed in the dark"; this factor also includes the item "Thunderstorms"), fear of animals (e.g., "Spiders"), fear of danger and death (e.g., "Being hit by a car or truck"), and medical fears (e.g., "Getting a shot from the doctor"; see Ollendick, 1983). Children rate their fear of each stimulus or situation on a 3-point scale (1=no fear, 2=some fear, 3=a lot of fear). Ratings are summed to yield a total fear score (range: 25-75) and factor/subscales scores (range 5-15).

\subsection{Statistical analysis}

The Statistical Package of Social Sciences (SPSS) was used to compute descriptive statistics, reliability coefficients, $t$-tests, and correlations. Differences in fear levels between the children of 
both countries were evaluated by means of univariate Analyses of Variance with age and gender as covariates (ANCOVAs). For dichotomous dependent variables, logistic regression analyses were carried out with country as the predictor variable. In these analyses, we controlled for gender and age by forcing these two variables into the equation on step 1 .

\section{Results}

\subsection{General statistics}

Table 1 presents descriptive statistics for HSQ and FSSC. As can be seen, internal consistency of both questionnaires was satisfactory. Cronbach's alphas were in the 0.80 range for HSQ fear of storm, around 0.90 for the FSSC total score, and generally well above 0.60 for the FSSC subscales in spite of the fact that these scales only contain five items. Furthermore, $t$-tests revealed that for both groups of children, there were significant gender differences with regard to HSQ fear of hurricanes $[t(159)=3.0, P<0.01$ for Antillean children and $t(162.4$, adjusted $d f)=4.0, P<0.01$ for Belgian children], HSQ fear of storms $[t(159)=3.2, P<0.01$ for Antillean children and $t(183)=5.3$,

Table 1

Mean fear scores (standard deviations) and reliability coefficients for the various measures in Antillean and Belgian children $^{\mathrm{a}}$

\begin{tabular}{lrrrl}
\hline & Total group & Boys & Girls & $\alpha$ \\
\hline Antillean children & $N=161$ & $n=61$ & $n=100$ & \\
$H S Q$ & & & & \\
Fear of hurricane & $2.1(0.8)$ & $1.8(0.8)$ & $2.2(0.7)^{\mathrm{b}}$ & \\
Fear of storm & $15.9(4.2)$ & $14.6(4.4)$ & $16.7(3.8)^{\mathrm{b}}$ & 0.81 \\
$F S S C$ short version & & & & \\
Total fear score & $46.9(9.9)$ & $42.8(9.8)$ & $49.5(9.2)^{\mathrm{b}}$ & 0.90 \\
Fear of danger and death & $12.4(4.7)$ & $11.4(3.0)$ & $12.9(2.3)^{\mathrm{b}}$ & 0.80 \\
Fear of the unknown & $8.4(2.8)$ & $7.6(2.4)$ & $9.0(2.8)^{\mathrm{b}}$ & 0.79 \\
Fear of animals & $8.4(2.4)$ & $7.4(2.0)$ & $9.0(2.4)^{\mathrm{b}}$ & 0.68 \\
Fear of failure and criticism & $8.8(2.3)$ & $8.1(2.4)$ & $9.2(2.2)^{\mathrm{b}}$ & 0.68 \\
Medical fears & $8.9(2.1)$ & $8.2(2.0)$ & $9.4(2.0)^{\mathrm{b}}$ & 0.47 \\
Belgium children & $N=185$ & $n=98$ & $n=87$ & \\
$H S Q$ & & & & \\
Fear of hurricane & $2.7(0.6)$ & $2.5(0.7)$ & $2.8(0.4)^{\mathrm{b}}$ & \\
Fear of storm & $14.9(3.6)$ & $13.7(3.2)$ & $16.3(3.5)^{\mathrm{b}}$ & 0.82 \\
$F S S C$ short version & & & & \\
Total fear score & $44.1(8.2)$ & $40.1(7.0)$ & $48.6(6.9)^{\mathrm{b}}$ & 0.88 \\
Fear of danger and death & $12.1(2.4)$ & $11.3(2.5)$ & $13.0(1.9)^{\mathrm{b}}$ & 0.77 \\
Fear of the unknown & $7.4(2.1)$ & $6.4(1.5)$ & $8.5(2.2)^{\mathrm{b}}$ & 0.72 \\
Fear of animals & $7.6(2.2)$ & $6.8(1.7)$ & $8.5(2.3)^{\mathrm{b}}$ & 0.74 \\
Fear of failure and criticism & $8.5(2.3)$ & $7.9(2.3)$ & $9.2(2.1)^{\mathrm{b}}$ & 0.76 \\
Medical fears & $8.5(2.1)$ & $7.7(1.7)$ & $9.4(2.2)^{\mathrm{b}}$ & 0.70 \\
\hline
\end{tabular}

${ }^{a}$ HSQ=Hurricane-Storm Questionnaire, FSSC=Fear Survey Schedule for Children.

b Significant gender difference at $P<0.05$. 
$P<0.01$ for Belgian children], and all fear scales of the FSSC [e.g., FSSC total score: $t(159)=4.3$, $P<0.01$ for Antillean children and $t(183)=8.3, P<0.01$ for Belgian children] (see Table 1). Finally, it should be noted that small, but significant associations were found between age and a number of fear scores. More specifically, in Antillean children, age correlated negatively with HSQ fear of hurricanes $(r=-0.16)$ and HSQ fear of storm $(r=-0.18)$, while in Belgian children, age correlated negatively with HSQ fear of storm $(r=-0.16)$, FSSC total fear score $(r=-0.15)$, and FSSC animal fears $(r=-0.15)$. The negative correlations indicate that these fears slightly decline with increasing age.

\subsection{Comparison of Antillean and Belgian children}

\subsubsection{Fear of hurricanes}

Mean ratings on the HSQ fear of hurricane item of Antillean and Belgian children were 2.1 $(\mathrm{SD}=0.8)$ and $2.7(\mathrm{SD}=0.6)$, respectively. As can be seen in Table 2, there were significantly more Belgian children endorsing a lot of fear to the Hurricane item than Antillean children (percentages being 73.5 vs 32.9 , respectively; Wald $\chi^{2}=64.0, P<0.01$ ). Thus, Belgian children reported more fear of hurricanes than Antillean children.

\subsubsection{Fear of storm}

Mean scores on the HSQ fear of storm scale were 15.9 ( $\mathrm{SD}=4.2)$ for Antillean children vs $14.9(\mathrm{SD}=3.6)$ for Belgian children. An ANCOVA showed that this difference was significant $[F(1,342)=6.3, P<0.05]$, indicating that Antillean children indeed were more fearful of storms than Belgian children.

A series of logistic regression analyses was performed to examine differences between both groups of children for separate items of the HSQ fear of storm scale (see Table 2). This analyses showed that Antillean children reported more fear of "The sound of the wind" (Wald $\chi^{2}=4.0$, $P<0.05$ ), "To be left alone" (Wald $\chi^{2}=36.9, P<0.01$ ), "To get hurt" (Wald $\chi^{2}=23.3, P<0.01$ ), and "That your parents can't pick you up on time from school" (Wald $\chi^{2}=9.1, P<0.01$ ) than Belgian children. Meanwhile, Belgian children reported more fear of "That the house is filled in with water" (Wald $\chi^{2}=13.9, P<0.01$ ).

\subsubsection{General fear levels}

An ANCOVA performed on the FSSC total scores revealed no significant differences in general fear levels between Antillean and Belgian children, means being 46.9 ( $\mathrm{SD}=9.9)$ vs 44.1 (SD=8.2), respectively $[F(1,342)=2.3, P=0.13]$. Additional ANCOVAs carried out on the FSSC subscales, however, showed that compared to Belgian children, Antillean children had higher scores on fear of the unknown [in particular "Thunderstorms" and "Being alone"; means being 7.4 (SD=2.1) vs $8.4(\mathrm{SD}=2.8), F(1,342)=7.7, P<0.01$ ] and fear of animals [in particular "Snakes"; means being $7.6(\mathrm{SD}=2.2)$ vs $8.4(\mathrm{SD}=2.4), F(1,342)=4.2, P<0.05]$.

\subsection{Connections between fear of hurricanes and storms and general fear levels}

Table 3 displays correlations (corrected for gender and age) between the fear measures used in the current study. Inspection of the correlations reveals that in both Antillean and Belgian 
Table 2

Percentages of Antillean and Belgium children who endorsed 3="a lot of fear" on HSQ items ${ }^{\mathrm{a}}$

\begin{tabular}{|c|c|c|c|c|c|c|c|c|}
\hline & \multicolumn{3}{|c|}{ Antillean children } & \multicolumn{3}{|c|}{ Belgium children } & \multicolumn{2}{|c|}{ Difference $^{b}$} \\
\hline & $\begin{array}{l}\text { Total } \\
\text { group } \\
(N=161)\end{array}$ & $\begin{array}{l}\text { Boys } \\
(n=61)\end{array}$ & $\begin{array}{l}\text { Girls } \\
(n=100)\end{array}$ & $\begin{array}{l}\text { Total } \\
\text { group } \\
(N=185)\end{array}$ & $\begin{array}{l}\text { Boys } \\
(n=98)\end{array}$ & $\begin{array}{l}\text { Girls } \\
(n=87)\end{array}$ & Wald $\chi^{2}$ & $P$ \\
\hline \multicolumn{9}{|l|}{$H S Q$} \\
\hline $\begin{array}{l}\text { A. How much do } \\
\text { you fear a } \\
\text { hurricane? }\end{array}$ & 32.9 & 23.0 & $39.0^{c}$ & 73.5 & 62.2 & $86.2^{\mathrm{c}}$ & 64.0 & $<0.001$ \\
\hline \multicolumn{9}{|c|}{ B. When there is a severe storm, how much do you fear ...? } \\
\hline $\begin{array}{l}\text { 1. The sound of } \\
\text { the wind }\end{array}$ & 8.1 & 6.6 & 9.0 & 1.6 & 0.0 & 3.4 & 4.0 & $<0.05$ \\
\hline $\begin{array}{l}\text { 2. Having no } \\
\text { light }\end{array}$ & 16.8 & 14.8 & 18.0 & 7.6 & 2.0 & $13.8^{\mathrm{c}}$ & 3.0 & ns \\
\hline $\begin{array}{l}\text { 3. To be left } \\
\text { alone }\end{array}$ & 49.1 & 49.2 & 49.0 & 13.5 & 3.1 & $25.3^{\mathrm{c}}$ & 36.9 & $<0.001$ \\
\hline 4. To get hurt & 46.0 & 31.1 & $55.0^{c}$ & 17.3 & 9.1 & $26.4^{\mathrm{c}}$ & 23.3 & $<0.001$ \\
\hline $\begin{array}{l}\text { 5. That the roof } \\
\text { of the house is } \\
\text { blowing off }\end{array}$ & 57.8 & 49.2 & 63.0 & 45.4 & 37.8 & $54.0^{c}$ & 2.4 & ns \\
\hline $\begin{array}{l}\text { 6. That the house } \\
\text { is filled in with } \\
\text { water }\end{array}$ & 27.3 & 23.0 & 30.0 & 44.3 & 36.7 & $52.9^{c}$ & 13.9 & $<0.001$ \\
\hline $\begin{array}{l}\text { 7. That your } \\
\text { parents can't pick } \\
\text { you up on time } \\
\text { from school }\end{array}$ & 26.1 & 14.8 & $33.0^{\mathrm{c}}$ & 11.4 & 7.1 & 16.1 & 9.1 & $<0.005$ \\
\hline $\begin{array}{l}\text { 8. That rocks are } \\
\text { falling down and } \\
\text { destroy the house }\end{array}$ & 45.3 & 37.7 & 50.0 & 56.8 & 50.0 & 64.4 & 2.6 & ns \\
\hline
\end{tabular}

a $\mathrm{HSQ}=$ Hurricane-Storm Questionnaire.

b Differences between Antillean and Belgium children were computed by means of logistic regression analyses in which age and gender were entered at step 1.

c Significant gender difference at $P<0.05$.

children, there was a signifant correlation between fear of hurricanes and fear of storms $(r$ being 0.57 and 0.52 , respectively, both $P_{\mathrm{s}}<0.01$ ). Furthermore, in both groups, fear of hurricanes and fear of storms were significantly associated with general fear levels as measured by the FSSC total score ( $r$ s between 0.46 and 0.73 , all $P \mathrm{~s}<0.01$ ). Finally, it should be noted that in Antillean children both fear of hurricanes and fear of storms were substantially connected to FSSC item "Thunderstorms" ( $r$ s being 0.45 and 0.55 , respectively, both $P_{\mathrm{s}}<0.01$ ). In Belgian children, these correlations were significantly lower $(r$ s being 0.22 and 0.37 , respectively, $P \mathrm{~s}<0.01$; $t$ s being 2.4 and 2.1, respectively, both $P_{\mathrm{s}}<0.05$ ). 
Table 3

Correlations (corrected for gender and age) between HSQ and FSSC indices computed for Antillean and Belgian children separately ${ }^{\mathrm{a}}$

\begin{tabular}{lll}
\hline & Fear of hurricane & Fear of storm \\
\hline $\begin{array}{l}\text { Antillean children } \\
H S Q\end{array}$ & & \\
Fear of hurricane & & \\
Fear of storm & 0.57 & \\
$F S S C$ short version & 0.52 & 0.73 \\
Total fear score & 0.45 & 0.55 \\
Fear of thunderstorms & & \\
Belgium children & & \\
HSQ & 0.52 & \\
Fear of hurricane & & \\
Fear of storm & & \\
$F S S C$ short version & 0.46 & 0.67 \\
Total fear score & 0.22 & 0.37 \\
Fear of thunderstorms &
\end{tabular}

${ }^{a} \mathrm{HSQ}=$ Hurricane-Storm Questionnaire, FSSC=Fear Survey Schedule for Children. All correlations were significant at $P<0.01$.

\subsection{Rank of 'fear of hurricanes'}

Table 4 displays the most common fears (percentages of children endorsing $3=a$ lot of fear) of Antillean and Belgian children. Note that, in both Antillean and Belgian children, FSSC fear of danger and death items (i.e., "Death or dead people", "Getting lost in a strange place", "Falling from high places", "Being hit by a car or truck", and "Not being able to breathe") were all present in the top 10 of most common fears. Most importantly, fear of hurricanes ranked 8th in the top 10 of Antillean children, whereas it was listed first among Belgian children.

\section{Discussion}

The main purpose of the current study was to assess fear of hurricanes in children who actually had been confronted with this dangerous natural event (i.e., Antillean children) and to compare their fear levels to those of children who are unfamiliar with such an event (i.e., Belgian children). The results can be catalogued as follows. First, as predicted, Antillean children reported significantly more fear of storms than Belgian children, despite the fact that both groups had more or less similar general fear levels. Second, contrary to our expectations, Antillean children reported lower levels of fear of hurricanes than Belgian children.

In his study on severe wheather phobia, Westefeld (1996) interviewed 81 adults who had a self-declared phobia of severe wheather. The large majority of them $(80 \%)$ indicated that the onset of the phobic complaints was related to a direct learning experience with a severe storm of some kind. On the one hand, the results of the present study are in keeping with the notion 
Table 4

Ranking of 'fear of hurricanes' among the most common FSSC fears (percentages of children rating 3='a lot of fear') of Antillean and Belgian children ${ }^{\mathrm{a}}$

\begin{tabular}{|c|c|c|c|c|c|c|c|}
\hline Antillean children & $\begin{array}{l}\text { Total } \\
\text { sample } \\
(N=161)\end{array}$ & $\begin{array}{l}\text { Boys } \\
(n=61)\end{array}$ & $\begin{array}{l}\text { Girls } \\
(n=100)\end{array}$ & Belgian children & $\begin{array}{l}\text { Total } \\
\text { sample } \\
(N=185)\end{array}$ & $\begin{array}{l}\text { Boys } \\
(n=98)\end{array}$ & $\begin{array}{l}\text { Girls } \\
(n=87)\end{array}$ \\
\hline $\begin{array}{l}\text { 1. Falling from high } \\
\text { places }\end{array}$ & 71.4 & 62.3 & $77.0^{\mathrm{b}}$ & 1. Hurricanes & 73.5 & 62.2 & $86.2^{\mathrm{b}}$ \\
\hline $\begin{array}{l}\text { 2. Being hit by a } \\
\text { car or truck }\end{array}$ & 70.8 & 55.7 & $80.0^{\mathrm{b}}$ & $\begin{array}{l}\text { 2. Being hit by a } \\
\text { car or truck }\end{array}$ & 60.0 & 50.0 & $71.3^{\mathrm{b}}$ \\
\hline $\begin{array}{l}\text { 3. Not being able to } \\
\text { breathe }\end{array}$ & 60.9 & 52.2 & 66.0 & $\begin{array}{l}\text { 3. Not being able to } \\
\text { breathe }\end{array}$ & 59.6 & 49.0 & $71.3^{\mathrm{b}}$ \\
\hline $\begin{array}{l}\text { 4. Getting a serious } \\
\text { disease }\end{array}$ & 58.4 & 50.8 & 63.0 & $\begin{array}{l}\text { 4. Falling from high } \\
\text { places }\end{array}$ & 57.8 & 44.9 & $72.4^{\mathrm{b}}$ \\
\hline $\begin{array}{l}\text { 5. Getting lost in a } \\
\text { strange place }\end{array}$ & 53.4 & 39.3 & $62.0^{\mathrm{b}}$ & $\begin{array}{l}\text { 5. Getting lost in a } \\
\text { strange place }\end{array}$ & 49.7 & 34.7 & $66.7^{\mathrm{b}}$ \\
\hline $\begin{array}{l}\text { 6. Death or dead } \\
\text { people }\end{array}$ & 52.2 & 42.6 & 58.0 & $\begin{array}{l}\text { 6. Getting a serious } \\
\text { disease }\end{array}$ & 46.7 & 35.7 & $60.9^{\mathrm{b}}$ \\
\hline 7. Snakes & 51.6 & 39.3 & $59.0^{\mathrm{b}}$ & $\begin{array}{l}\text { 7. Death or dead } \\
\text { people }\end{array}$ & 35.7 & 22.4 & $50.6^{\mathrm{b}}$ \\
\hline 8. Hurricanes & 32.9 & 23.0 & $39.0^{\mathrm{b}}$ & 8. Snakes & 22.7 & 14.3 & $32.2^{\mathrm{b}}$ \\
\hline $\begin{array}{l}\text { 9. Being sent to the } \\
\text { principal }\end{array}$ & 31.1 & 27.9 & 33.0 & $\begin{array}{l}\text { 9. Having to go to } \\
\text { the hospital }\end{array}$ & 21.6 & 13.3 & $31.0^{\mathrm{b}}$ \\
\hline 10. Failing a test & 30.4 & 23.0 & 35.0 & 10. Failing a test & 20.5 & 18.4 & 23.0 \\
\hline
\end{tabular}

${ }^{\text {a }}$ FSSC=Fear Survey Schedule for Children.

b Significant gender difference at $P<0.05$.

that direct learning experiences (i.e., exposure to a threatening event such as an hurricane) may promote children's fears. That is, Antillean children who had been exposed to severe storms and their consequences were more fearful of storms than Belgian children who are relatively unfamiliar with such events. On the other hand, the findings do not fully support a conditioning account of children's fears as Antillean children reported less fear of hurricanes than Belgian children. At first sight, these findings seem difficult to reconcile. However, the following considerations suggest that they are less conflicting than one may assume. To begin with, it is important to note that both Antillean and Belgian children are familiar with storms and obviously both groups of children used their own frame of reference when completing the HSQ fear of storm items. Given the fact that storms (e.g., hurricanes) in the Carribean are simply more severe than storms in Western Europe, it is not surprising that Antillean children had more fear of storms than Belgian children. Interestingly, while Antillean children scored significantly higher on most HSQ fear of storm items, Belgian children more frequently endorsed the item "That the house is filled in with water". Indeed, during the past few years, countries in Western Europe (including Belgium) have been regularly confronted with floods due to bad weather conditions and heavy rain falls. Second, when Antillean children rated their level of fear of hurricanes, they probably used their own experiences with this phenomenon. In contrast, Belgian children had to rely on indirect and probably dramatized sources of information about hurricanes (e.g., seeing the consequences of an 
hurricane on television). In other words, when rating their fear level to hurricanes, Antillean children might have replied in terms of how fearful they actually were at the time when their island was ravaged by a hurricane, whereas Belgian children might have responded in terms of how fearful one could be of such an event. In the former case, there are reality constraints, while in the latter case such constraints are lacking. Indeed, research by Tesser (1976) has suggested that in the absence of reality constraints, fear ratings tend to polarize. It is important to note that the current data provided some support for this line of reasoning. That is, HSQ scores were more substantially connected to FSSC 'fear of thunderstorms' in Antillean than in Belgian children. This seems to indicate that Antillean children provided more valid ratings of their fear of storms and hurricanes than Belgian children.

The latter point nicely illustrates how differences in interpretation of a fear item (such as hurricanes) heavily influences the outcome of fear surveys. It is clear that this observation has some implications for the assessment of fears in children. For example, a measure like the FSSC contains many items referring to dangerous situations such as "Being hit by a car", "Earthquakes", and "Bombing attacks". Obviously, children's ratings of such items are in the majority of cases not based on actual experiences with such situations and thus probably reflect children's appraisal of threat in case they would be confronted with such events. Precisely for this reason, measures as the FSSC have been criticized (see McCathie \& Spence, 1991). There is some consensus among researchers that this type of questionnaires is more useful for assessing general fearfulness than for identifying specific fears (e.g., Stallings \& March, 1995).

The present study replicates a number of general findings that have been reported earlier in the literature on normal childhood fears (see Craske, 1997; Gullone, 2000; Muris \& Merckelbach, 2001). First of all, girls displayed higher levels of fears than boys and this was not only the case for general fears as measured with the FSSC, but also for fear of storms and hurricanes. Second, although the age range was rather restricted in the present study, a number of negative correlations between age and fears were found which indicates that these fears declined with increasing age. Third, children's fear of storms and hurricanes were significantly associated with other FSSC fear scales. Thus, fears in one specific domain appear to correlate substantially with fears in other domains, suggesting a higher order trait of fearfulness (see also Gullone \& King, 1997). Fourth and finally, although some indications were found for the presence of fears that were highly specific and idiosyncratic to each country (e.g., snakes in Antillean children; floods in Belgian children), the current data are in keeping with previous studies showing that the rank order of most common fears as well as general fear levels are quite comparable among children from different cultures (e.g., Ollendick et al., 1996).

Several shortcomings of the present study must be acknowledged. First of all, the present study solely relied on children's self-report. Second, it should be borne in mind that Antillean and Belgian children were quite different with respect to ethnical background, percentage of children coming from divorced families, and probably socio-economic status. Third, no exact information about actual experiences with hurricanes of individual Antillean children was available. Such information could have yielded interesting additional information about the connection between conditioning experiences and fear of storms and hurricanes.

Despite these limitations, our data to some extent support the idea that direct learning experiences may promote children's fears. That is, Antillean children who had actual experience with severe storms (i.e., hurricanes) were more fearful of storms than Belgian children who are rela- 
tively unfamiliar with such events. The unexpected finding that Antillean children displayed lower fear levels to the item "Hurricanes" than Belgian children makes clear that researchers and clinicians should be careful in drawing conclusions from a single fear item as children may differ considerably in how they interpret such item. Using a scale with multiple items tapping various potentially fearful aspects of an event is a better way to assess children's fear of a specific situation.

\section{Acknowledgements}

The corporation SIFMA, and the primary schools: Oranje school, Christian Hillside, St Peters Public School, Methodic Agogic Centre, and Marie Laurence School on St Maarten, Netherlands Antilles, are thanked for their participation in this study.

\section{References}

Craske, M. G. (1997). Fear and anxiety in children and adolescents. Bulletin of the Menninger Clinic, 61, 4-34.

Dollinger, S. T., O’Donnell, J. P., \& Staley, A. A. (1984). Lightning-strike disaster: effects on children's fears and worries. Journal of Consulting and Clinical Psychology, 52, 1028-1038.

Gullone, E. (2000). The development of normal fear: a century of research. Clinical Psychology Review, 20, 429-451.

Gullone, E., \& King, N. J. (1997). Three-year follow-up of normal fear in children and adolescents aged 7 to 18 years. British Journal of Developmental Psychology, 15, 97-111.

King, N. J., Gullone, E., \& Ollendick, T. H. (1998). Etiology of childhood phobias: current status of Rachman's three pathways theory. Behaviour Research and Therapy, 36, 297-309.

King, N. J., Hamilton, D. I., \& Ollendick, T. H. (1988). Children's phobias: A behavioural perspective. Chichester: Wiley.

McCathie, H., \& Spence, S. H. (1991). What is the Revised Fear Survey Schedule for Children measuring? Behaviour Research and Therapy, 29, 495-502.

Muris, P., \& Merckelbach, H. (2001). The etiology of childhood specific phobias: a multifactorial model. In M. W. Vasey, \& M. Dadds, The developmental psychopathology of anxiety (pp. 355-385). New York: Oxford University Press.

Ollendick, T. H. (1983). Reliability and validity of the Revised Fear Survey Schedule for Children (FSSC-R). Behaviour Research and Therapy, 21, 685-692.

Ollendick, T. H., \& King, N. J. (1991). Origins of childhood fears: an evaluation of Rachman's theory of fear acquisition. Behaviour Research and Therapy, 29, 117-123.

Ollendick, T. H., \& King, N. J. (1994). Fear and their level of interference in adolescents. Behaviour Research and Therapy, 32, 635-638.

Ollendick, T. H., King, N. J., \& Frary, R. B. (1989). Fears in children and adolescents: reliability and generalizability across gender, age, and nationality. Behaviour Research and Therapy, 27, 19-26.

Ollendick, T. H., King, N. J., \& Muris, P. (submitted). Fears and phobias in children: phenomenology, epidemiology and etiology.

Ollendick, T. H., Yang, B., King, N. J., Dong, Q., \& Akande, A. (1996). Fears in American, Australian, Chinese, and Nigerian children and adolescents: a cross-cultural study. Journal of Child Psychology and Psychiatry, 37, 213-220.

Ollendick, T. H., Yule, W., \& Ollier, K. (1991). Fears in British children and their relationship to manifest anxiety and depression. Journal of Child Psychology and Psychiatry, 32, 321-331.

Rachman, S. J. (1977). The conditioning theory of fear acquisition: a critical examination. Behaviour Research and Therapy, 15, 375-387. 
Stallings, P., \& March, J. S. (1995). Assessment. In J. S. March, Anxiety disorders in children and adolescents (pp. 125-147). New York: Guilford Press.

Tesser, A. (1976). Thought and reality constraints as determinants of attitude polarization. Journal of Research in Personality, 10, 183-194.

Westefeld, J. S. (1996). Severe wheather phobia: an exploratory study. Journal of Clinical Psychology, 52, 504-515.

Yule, W., Udwin, O., \& Murdoch, K. (1990). The 'Jupiter' sinking: effects on children's fears, depression and anxiety. Journal of Child Psychology and Psychiatry, 31, 1051-1061. 